Eren, M. V. / Journal of Yasar University, 2020, 15/59, 598-614

\title{
Cinsiyet Eşit(siz)liğinde Genç Kadın İşsizliği ile Kalkınma Arasındaki İlişki: Avrupa Birliği Ülkeleri Üzerine Ekonometrik Bir Analiz
}

\section{The Relationship between Youth Female Unemployment and Development In Gender (In)Equality: An Econometric Analysis on European Union Countries}

\author{
Mehmet Vahit EREN, Kilis 7 Aralık Üniversitesi, Türkiye, mvahiteren@gmail.com \\ Orcid No: 0000-0003-0348-0137
}

Öz: Sürdürülebilir kalkınma hedeflerinden biri, toplumsal cinsiyet eşitliğinin sağlanmasıdır. İstihdamda cinsiyet ayrımcıllğının yaşanması, cinsiyet eşitliğinin toplumsal faydasını azaltmaktadır. Bu çalışmanın amacı, genç kadın işsizliği ile kalkınma arasındaki ilişkiyi Avrupa Birliği ülkelerine ait veriler aracılığılla araştırmaktır. Çalışma için 1991-2018 dönemi verileri ve panel veri analizi yöntemi kullanılmıştır. Çalışmadan elde edilen bulgular, genç kadın işsizliğinden kalkınmaya doğru tek yönlü nedensellik ilişkisi olduğunu göstermektedir. Bu sonuca göre, Avrupa Birliği ülkelerinde kadınların kalkınma sürecinde önemli bir rolü olduğu ifade edilebilmektedir.

\section{Anahtar Kelimeler: Toplumsal Cinsiyet Eşitliği, Genç Kadın İsssizliği, Kalkınma, Avrupa Birliği} JEL Siniflandirmast: J64, J71, O15

\begin{abstract}
One of the sustainable development goals is to ensure gender equality. Gender discrimination in employment reduces the social benefit of gender equality. The aim of this study is to investigate the relationship between youth female unemployment and development through data belonging to European Union countries. 1991-2018 period data and panel data analysis method were used for the study. Findings obtained from the analysis show that there is unidirectional causality from youth female unemployment to development. According to the result, it can be stated that women play an important role in the development process in European Union countries.
\end{abstract}

Keywords: Gender Equality, Youth Female Unemployment, Development, European Union JEL Classification: J64, J71, O15

\section{Giriş}

Kadın ve erkeklerin hayatın her alanında (ekonomik, sosyal, siyasal, kültürel) eşit hak ve imkanlara sahip olması olarak ifade edilen toplumsal cinsiyet eşitliği, insanların en temel haklarından biridir. Cinsiyet farklılıkları sebebiyle ayrımcılık yapılanların bu olanaklardan yararlanamaması durumunda, cinsiyet eşitsizliğinin gün yüzüne çıkması ve tartışılan konuların başında gelmesine yol açmaktadır. Söz konusu eşitliğin sağlanması halinde sadece kadınlar değil, erkekler için de herhangi bir alanda bir ayrımcılık yapılmayacak, toplumsal huzur ve verimlilik daha yüksek olacaktır. Kadınların işgücüne katılımı, kadın işsizliği, kadınların elde ettiği ücret düzeyleri, kadın istihdamı gibi değişkenler ekonomik anlamda cinsiyet eşitsizliğini göstermektedir. Sürdürülebilir kalkınmada, cinsiyet eşitliğinin sağlanması en önemli hedeflerden birisidir ki, bu durum kadınların işgücüne katılımının ülke kalkınmasında ne kadar önemli bir

\section{Makale Gecmiși / Article History}

Başvuru Tarihi / Date of Application

Kabul Tarihi / Acceptance Date

: 24 Nisan/ April 2020

(C) 2020 Journal of Yaşar University. Published by Yaşar University. Journal of Yaşar University is an open access journal. There is no conflict of interest or ethical concern regarding this publication. 
rol üstlendiğini belirtmektedir. Cinsiyet eşitsizliğinin yaşandığı ülkelerde beşeri sermaye kaynağı olarak kadının verimliliğinden faydalanılamamasından dolayı ekonomik büyüme ve kalkınma olumsuz etkilenmektedir. Üretim faktörü olarak kadın işgücünün ekonomiye kazandırılması gerekmektedir. Bu sebeple, sürdürülebilir bir kalkınma için cinsiyet eşitsizliği sorununun çözüme kavuşturulması önem arz etmektedir.

İşsizlik, gelişmişlik düzeyi ne olursa olsun ülkelerin karşılaştığı en önemli sorunlardan biri olup, bu sorundan en fazla etkilenen kesim ise gençlerdir. Genç bireyler, eğitimini henüz tamamlamamış, temel eğitimin dışında iş piyasasında yer alabilmek için gerekli olan eğitimleri almaya devam eden, algısı açık, yeteneklerini keşfettiğinde ülkeye katkı sağlayacak, ülke ekonomilerinin büyüme ve kalkınmalarında önemli bir itici güç olan, toplumun en dinamik kesimini oluşturur. Yeni yüzyılın en büyük sorunlarından genç işsizliğinin oluşmasında yeterli iş imkanlarının oluşturulamaması, tecrübe eksikliği, işin gerektirdiğgi bilgilere sahip olamama veya eğitimin verilememesi, istihdamsı büyüme gibi birçok nedenin etkisi bulunmaktadır. Uzun vadede kalkınma hedeflerinin gerçekleştirilebilmesi için gençlerin istihdam edilmesi, üretken kaynak olarak verimliliklerinden faydalanılması önemlidir. Önemli olan bir diğer husus ise, gençlerin istihdamında cinsiyet ayrımcılığının yapılmamasıdır. Her ne kadar toplumda daha önceleri üretime katılma rolü erkeklere verilmiş olsa da, günümüzde artık kadınlar da üretimden pay almaktadır. Özellikle sanayi devriminden sonra küreselleşen dünyada refah düzeyinin artması ve ülkeler arasında kalkınmışlık farklarının azaltılmasında kadının istihdam edilmesi, atıl bir kaynak olmak yerine bireysel ve toplumsal bazda olumlu sonuçlar doğurmaktadır.

Tüm dünyada olduğu gibi Avrupa Birliği (AB) ülkelerinde de genç nüfus, işsizlik sorunuyla karş1 karşıya kalmaktadır. Her ne kadar Birlik ülkeleri dünyanın en gelişmiş ülkeleri de olsa, bu sorunla başa çıkmak durumundadır. Aynı zamanda bu sorunla mücadele ederken, cinsiyet farklarını azaltmayı da dikkate almaları önem arz etmektedir. Bu bağlamda, çalışmanın ortaya çıkış noktası, Avrupa Birliği’nde kalkınmanın sürdürülebilirliğini gerçekleştirmek amacıyla genç kadın işsizliğinin önemli bir faktör olup olmadığ1 sorusudur. Buradan hareketle çalışmanın hipotezi, "AB'de genç kadın işsizliği ile kalkınma arasında bir ilişki vardır” şeklinde kurulmuştur.

Çalışmada, AB ülkelerinde genç kadın işsizliği ile kalkınma arasındaki ilişki araştırılmaktadır. Bu araştırma yapılırken, panel veri analizi yöntemi kullanılmaktadır. Bu yöntemde, güncel teknikler kullanılarak literatüre katkı yapacak bir çalışma ortaya çıkarılması planlanmaktadır. Ayrıca çalışmada, genç kadın işsizliği ile insani gelişme endeksini kullanan çalışmaya rastlanılmadığından diğer çalışmalardan ayrılmaktadır. Çalışmada ilk olarak konu ile ilgili genel bir bilgilerin yer aldığı giriş bölümü, devamında genç işsizlik, cinsiyet eşitsizliği, cinsiyet eşitliği ile sürdürülebilir kalkınma ilişkisi, AB'de işsizliğe bakış ve istihdam stratejisi, cinsiyet eşitsizliği ile mücadele politikaları ile ilgili teorik bilgi ve verilerin bulunduğu ikinci bölüm bulunmaktadır. Devamında konu ile ilgili daha önce yapılmış olan uygulamalı çalışmaların özetlendiği literatür taramasının olduğu üçüncü bölüm yer almaktadır. Dördüncü bölümde ise, çalışmanın konusunu oluşturan analiz gerçekleştirilmekte ve bulgular sunulmaktadır. Son olarak, sonuç bölümünde analizden elde edilen sonuçlar ve politika önerileri ile çalışma nihai halini almaktadır.

\section{Teorik Çerçeve}

Bu bölümde genç işsizlik, cinsiyet eşitsizliği, cinsiyet eşitliği ile sürdürülebilir kalkınma ilişkisi, AB'de işsizliğe cinsiyetçi bakış ve istihdam stratejisi, cinsiyet eşitsizliği ile mücadele politikaları hakkında teorik bilgi ve verilere yer verilmiştir.

\subsection{Genç İşsizlik}

Uluslararası çalışma örgütü (ILO)'ne göre, 15-24 yaş aralığında yer alan bireyler genç olarak nitelenmekte, dolayısıyla söz konusu bireylerin işsiz kalması durumu genç işsizlik olarak ifade edilmektedir. Gelişmişlik düzeyi ne olursa olsun geçmişten günümüze sosyal ve ekonomik açıdan en önemli göstergelerin başında gelmektedir. İşsizlik toplumun bütününü ilgilendiren bir değişken olduğu, hele de dezavantajlı gruplar (özürlüler, engelliler, kadınlar, hükümlüler, niteliksiz işgücü) işsizlikten ekonomik ve sosyal bakımdan 
daha fazla etkilenmektedir. Ancak işsizlikten etkilenen bir diğer grup ise 15-24 yaş arası gençlerin oluşturduğu gruptur ki üzerinde durulması ve çözülmesi gereken en önemli işsizlik türüdür (Cenger ve Çütcü, 2018:491). Verimli nüfusun büyük bir bölümünü oluşturduklarından herhangi bir toplumda gençler, önemli bir sosyal, politik ve ekonomik güç oluşturmaktadır (Nwogwugwu ve Irechukwu, 2015:27).

Genç işsizliğin nedenlerinden bahsetmek gerekirse Gündoğan (1999:68)'a göre, genç işsizliğin yüksek düzeylerde seyretmesinin iki temel nedeni vardır. İlki, ekonomik büyümenin düşük seviyelerde kalması, konjonktürel dalgalanmaların yaşanması ve ücretlerin yüksek/düşük olması, genç işgücüne talebin/arzın yetersiz kalmasına yol açmaktadır. İkincisi ise, genç işgücünün niteliksiz olması, deneyim ve tecrübelerinin iş aleminin talebine cevap verecek düzeylerde olmamasıdır. Bu noktada gençlerin aldıkları eğitim düzeyine vurgu yapılmaktadır. Taş vd. (2018:283) ise, bahsi geçen nedenlere ilaveten işgücü piyasasında iş arayanlarla, istihdam imkanı sağlayacak olanlarla yeterli bilgi akışının olmaması ve genç nüfusun artış göstermesini genç işsizliğin nedenleri olabileceğini belirtmektedir. Taş ve Bilen (2014:55)'e göre, gençlere has nitelikler, gençlerin çalışma istekleri, gençlerin piyasaya ilk kez giriş yapması, etnik köken ve engellilik durumlarının da gençlerin işsiz kalmasına yol açan mikro nedenler arasında sayılabilmektedir.

Genç işsizliğinin (ve/veya aslında yetişkin işsizliğinin) oldukça belirgin ve önemli bir nedeni ise, işgücüne katılımdır. İşgücüne katılım oranı, işgücünün büyüklüğüne olan etkisi ile genç işsizliğin seviyesini etkileyecektir. Diğer faktörler sabit olduğunda, daha yüksek bir işgücüne katılım oranı, daha yüksek bir işsizlik oranı anlamına gelecektir. Bu bağlamda, asgari ücretteki bir artış, işgücü arzı üzerindeki pozitif etkisiyle hem işsizliği hem de istihdamı artırabilir. Üzerinde durulması gereken ilgili nokta, işin daha cazip hale gelmesi nedeniyle iş piyasasına daha fazla insanın iş aramak için girmesidir. Bununla birlikte, böyle bir artış mevcut ek işleri geçebilir, bu nedenle ölçülen işsizlik oranı artacaktır. Aynı zamanda, yüksek düzeyde işsizlik, işçileri işgücü piyasasına girmekten caydırma eğiliminde olacaktır. Neredeyse iş bulma şansı yoksa onu aramanın amacının ne olduğu sorusu akıllara gelecektir. Dolayısıyla işsizlik ve işgücüne katılımın ikili bir ilişkisi vardır (O’Higgins, 1997:17).

Genç işsizlik, gerek genç bireylerin gerekse ülkelerin geleceği bakımından çözülmesi elzem olan konuların başında gelmektedir. Nitekim, gençlik döneminde verilen eğitimden en fazla yararın elde edildiği dönemdir. Gençler, yeni bilgileri, fikirleri daha kolay anlamakta, yeni teknikleri daha hızlı öğrenebilmektedir. Şayet bir insana bu dönemde gerekli mesleki eğitim verilmez ise bu durum, gencin ilerideki mesleki kariyerini ve toplumdaki yerini etkileyebilir (Gündoğan, 1999:70). Dolayısıyla, bu sorunun çözülmemesi halinde, hem gençlerin tüm hayatı olumsuz etkilenecek hem de ülkelerin şu anda sahibi olduğu beşeri sermayeden gelecek dönemlerde faydalanamayacaktır. Ayrıca, genç işsizliği sosyal sonuçları da olan bir sorun olup, gençlerin iş bulamaması halinde birey meşru olmayan yollardan (hırsızlık yaparak vb) gelir etmeye başlar ve toplumun huzurunu bozduğu gibi işsizlik psikolojisiyle aile içi huzursuzluklar ve statü kaybı ortaya çıkabilmektedir (Özcan vd., 2016:93). Genç birey, iş bulamadığında işgücü piyasasında rakipleriyle girdiği iş bulma mücadelesinde başarısız olduğu ve hayatında önemli bir yenilgi aldığını düşünmektedir. Bu durum sonrasında, genç birey toplumdan kendini geri çekmekte ve içine kapanan, asosyal bir kişiliğe bürünmektedir. ABD'de yapılan bir araştırmadan elde edilen bulgular, işsiz kalan gençlerin suç işlemeye meyilli olduklarını göstermektedir. İtalya'da ise genç işsizlerin yer altı ekonomisine dahil olduklarını gösteren bir çalışma göze çarpmaktadır (Açıkgöz, 2017:12).

\subsection{Cinsiyet Eşitsizliğ̈i}

"Cinsiyet" kavramı, biyolojik bir olgu olup, bireyin kadın ya da erkek olarak mevcut biyolojik farklılıklara vurgu yapmaktadır (Türkmen, 2016:211). "Toplumsal cinsiyet" kavramı ise, sosyolojik bir olgu olup, kadınlar ile erkeklerin toplumsal olarak belirlenen rol ve sorumluluklara sahip olması ve zaman içinde değişebilmesi ve değiştirilebilmesi olarak ifade edilmektedir (Aytaç, 2018:328). Ayrımcılık, en genel ifadeyle "eşit olanlara veya farklı konumdakilere keyfi olarak eşit davranmamak" veya "bir kişinin bir gruba mensup olması veya bir niteliği nedeniyle diğerlerine nazaran farklı muamele görmesi ve mağdur edilmesi” olarak tanımlanmaktadır. Cinsiyete dayalı ayrımcılık, ayrımcılığın en bilinen şekli olup, bir kadına cinsiyeti sebebiyle bir erkeğe yapılan muameleden daha kötü ya da daha az iyi davranılması sonucu ortaya çıkmaktadır (Kırkpınar, 2016:68). Toplumsal cinsiyet ayrımından ötürü kadın ve erkekler arasında 
hayatın ekonomik, kültürel, siyasi ve sosyal alanlarında bir eşitsizlik durumu meydana gelmektedir (Durgun ve Gök, 2017:21).

Tarihsel süreç içerisinde kadın emeği resmi belgelerde neredeyse hiç görülmemektedir (Nasıroğlu, 2017:2246). Geçmişten günümüze toplumsal cinsiyet temelinde olan eşitsizlikten en fazla etkilenen cinsiyetin kadın olduğu kabul edilmektedir. Kadınlara karşı ayrımcılık, dünyanın neredeyse her ülkesinde karşımıza çıkmakta; ancak, farklı şekillerde görülmektedir. Kadınlar siyasal, sosyal, yasal ve ekonomik haklara sahip olmada ve bu hakları kullanmada, özel mülkiyet edinmede eşitsizliklere uğramaktadır. Geleneksel yaklaşımların etkin olduğu bazı toplumlarda kız çocukları, erkeklere göre değersiz görüldüğünden eğitim imkanlarına ulaşmada sıkıntılar yaşamaktadır. Ekonomik alanda da birçok eşitsizlik söz konusu olup, aile reisliği, iş kurma ve yönetme, mülkleri yönetme gibi konularda erkeklerle eşit şartlara sahip değildir. Kadınlar daha çok kayıt dışı sektörlerde, geçici, gündelik/yarı zamanlı, düşük ücretli, kötü koşullarda çalışmakta; pazarlık gücüne sahip olmadıklarından işe alınmada, ücret ve terfi iyileştirmelerinde de ayrımcılığa maruz kalmaktadır (Üner, 2008:7-8).

Ekonomik cinsiyet eşitsizliğinin boyutları göz önüne alındığında, kadınların resmi iş sektöründeki erkeklerden daha az kazandığı, yoksulluk içinde yaşama olasılığ 1 daha yüksek, resmi iş sektörüne katılma olasılığ1 daha düşüktür ve hanehalkı sektörü olarak evde yapılması gereken işlerde daha fazla pay1 bulunmaktadır (Jacobsen, 2011:1). Ailenin geçimini erkek sağlamakta ve kadınların çoğu ev hanımı olmayı tercih etmektedir. Ev işleriyle uğraşan kadın, resmi olarak çalışmamakta, dolayısıyla hanehalkı sektöründe kullanılan emeğin ürettiği ürün ve hizmetlerin ekonomik değeri bulunmamaktadır (Yavuz, 2016:78).

Toplumsal cinsiyet eşitsizliği, ülkelerin gelişmişlik düzeyi ne kadar yüksek olursa olsun dünyanın her bölgesinde karşılaşılabilen bir durumdur. Yıllardır devam eden ve uygarlaşma düzeyi yükselse de hala düzenlemelerin noksan olduğu, alınan birçok karara karşın, pratikte devletlerin alınan kararları tam olarak hayata geçiremediği, arka plana attığı konuların başında gelmektedir. Son yıllarda ülkeleri kalkınma düzeyleri açısından değerlendirmeye çalışan araştırmalarda toplumsal cinsiyet eşitsizliği önemli bir değişken olarak ele alınmaktadır. Toplumsal cinsiyet ayrımcılığının olmaması, eşitliğinin sağlanması sürdürülebilir kalkınmanın itici gücü ve/veya anahtarı olduğu görüşü kabul edilmektedir (Durgun ve Gök, 2017:21). Bu bağlamda, cinsiyet ayrımcılığını azaltmak için kadın işgücüne olan talebin artırılması gereklidir. Kadın işçiliğine olan yüksek talep, kadınların toplumdaki statü seviyelerini artırmaları ve işgücü piyasasında erkeklerle karşılaştırıldığında aktif olmaları için en etkili araçtır (İnce Yenilmez, 2017:328).

\subsection{Cinsiyet Eşitliği ve Sürdürrülebilir Kalkınma İlişkisi}

Yeni kalkınma paradigması olarak sürdürülebilir kalkınma, toplumsal cinsiyet eşitliği, sosyal adalet ve barışı sağlama potansiyeli olan bir kavramdır. Binyıl Kalkınma Hedefleri’nde yoksulluk, açlık, hastalıklar, cinsiyet eşitsizliğinin azaltılması ve temiz suya erişimin artırılması gibi temel sorunlar gündem konusudur. Ayrıca, cinsiyet eşitliği ve kadınların güçlendirilmesi ile ilgili temel bir hedef olduğu gibi birçok alt hedef de bulunmaktadır. Kadınların tüm boyutlarıyla eşit haklara sahip olarak toplumda daha fazla fayda sağlamalarını sağlama amacı taşımaktadır (Montiel, 2018:544).

Cinsiyet eşitliğinin sağlanması, iyi yönetişim, insan hakları, çevresel sürdürülebilirlik ve yoksulluğun azaltılması gibi diğer sürdürülebilir kalkınma hedefleriyle bağlantılıdır. Kalkınma hedefi olarak kadının güçlenmesinin iki temel etkisi vardır ki, peşinden gitmeye değer olan sosyal adaletin insan refahını sağlamada önemli bir etkisi olduğu ve sürdürülebilir insani kalkınmayı teşvik etmek için bir araç olduğudur. $\mathrm{Bu}$ nedenle, ulusal kalkınmayı ve süreçlerini teşvik etmek, hem erkeklerin hem de kadınların tüm potansiyellerini geliştirmede özgür olmalarını ve cinsiyet rolünü kısıtlayıcı etkiler olmadan seçimler yapabilmelerini sağlamaktır. Eğer herhangi bir ulusun sürdürülebilir kalkınmayı başarması gerekiyorsa, kadın ve erkeklerin ihtiyaç ve menfaatlerinin eşit derecede değer kazanması ve korunması gerekmektedir. Daha da önemlisi, yüksek cinsiyet açığı olan ülkelerin düşük büyüme ve refah göstergelerine (yetersiz beslenme, yüksek anne ölüm oran1, yüksek bebek ölüm oran1, yüksek yoksulluk oranı, düşük ömür beklentisi, düşük eğitim seviyesi ve diğerlerinin yanı sıra çoğunlukla tarım topluluğu olması (düşük endüstriyel büyüme)) sahip olduğu tespit edilmiştir (Aina, 2011:1). 
Kadınlara ve kız çocuklarına yatırım (eğitimlerine, sağlıklarına ve kazançlı faaliyetlerine) yapmak yoksul ekonomiler üzerinde çarpan etkisi yapabilmektedir. Bununla birlikte, cinsiyete özgü projelere odaklanan ikili ve çok taraflı yardımların payı \%30 civarında olup, yetersiz kalmaktadır. Bankalar ve bağışçılar, kadınları ekonomik kalkınmada aktif oyuncular olarak görmelidir. Daha fazla yardım, kadınların evdeki geleneksel rollerine, sağlık hizmetlerine, beslenme ve tarıma dayalı gelir getirici girişimlerin arttırılmasına odaklanmalıdır. Cinsiyete duyarlı kalkınma yardımı, kadınların toprak, işgücü ve ürün pazarlarında rekabet edebilmelerini sağlamak ve sürdürülebilir kalkınmaya ekonomik, sosyal ve çevresel katkılarda bulunmalarını sağlamak için güçlü bir araç olabilir (Stevens, 2010:3).

Sürdürülebilir kalkınmada kadınların işgücüne katılımının ve istihdam olanaklarının artırılması önem arz etmektedir. Gelişmekte olan ülkelerde olduğu gibi gelişmiş ülkelerde de kadınların işgücüne katılımının daha cazip hale getirilmesi veya ulaşılan düzeyin sürdürülebilir olması, kadınların kalkınma ve büyümeden daha fazla pay almalarına ve refah seviyesinin yükselmesine yol açmaktadır. Bilindiği üzere, üretim faktörleri arasında yer alan işgücünün, özellikle de kadın işgücünün atıl kalması üretim kaybına, düşük büyümeye ve kalkınma hızının azalmasına neden olmaktadır. Bu sebeple, kadınların ekonomiye kazandırılması, ülke geneli için bir kazanç ve sürdürülebilir büyüme/kalkınma hedeflerine ulaşmada önemli faktör olacaktır (Özdemir vd., 2012:115).

Cinsiyet eşitsizliği sorunu, kalkınmada önemli bir yeri olan ekonomik verimsizliğe yol açarak, kadın ve erkeklerin elde edilen üretimden alacağı pay arasında bir dengesizlik oluşturmakta; insani kalkınmanın temel faktörlerinden kadınlar aleyhine sonuçlar doğurabilmektedir. Bahsi geçen sonuç, kadınların verimliliği üzerinde olumsuz etki meydana getirerek ekonomik büyüme ve kalkınma hızını düşürebilmektedir. Bu nedenle, ekonomik büyüme ve kalkınmada istikrarın sağlanabilmesi için cinsiyet eşitsizliği probleminin çözümü önemli bir unsurlar arasında yerini almaktadır (Şimşek, 2010:235).

Günümüzde yoksulluğun azaltılması, gelecekteki çevresel bozulma ve sosyal ve ekonomik eşitsizlikler olmadan, toplumsal cinsiyete dayalı farklılıklara dikkat etmeden elde edilmesi veya sürdürülmesi mümkün görünmemektedir. Daha sık olarak, kadınlar ve kız çocukları cinsiyet eşitsizliğinin yükünü taşımaktadır. Toplumsal olarak oluşturdukları rolleri nedeniyle, erkekler ve erkek çocukları kadınlara ve kız çocuklarına göre, genellikle kaynaklara, karar almalara ve sosyal, politik ve ekonomik firsatlardan faydalanma kapasitelerine erişme konusunda bir avantaja sahiptir. Kalkınma müdahalelerinin sürdürülebilirliğini ve etkinliğini arttırmak için bu farklılıkların anlaşılması ve politika ve programlara dahil edilmesi gerekmektedir (The World Bank, 2002:1).

\subsection{AB'de İşsizliğe Bakış ve İstihdam Stratejisi}

Kadınların sadece işgücüne katılımı değil, aynı zamanda iş bulma olasılığg da düşüktür ki, 2018 yılı itibariyle kadınların küresel işsizlik oranı, erkeklerinkinden (\%4.7) 0.7 puan daha yüksek olup, \%5.4'dır. Kadınların işsizlik oranı, erkeklerinkinin 1.15 katıdır. İlerleyen dönemlerde, bu oranın gelişmiş ülkelerde sabit kalması, gelişmekte olan ülkelerde ise artacağı ve son on yılda gözlemlenen küresel işsizlik açısından kadınların göreceli konumlarında bozulmanın devam edeceği tahmin edilmektedir. Kuzey, Güney ve Batı Avrupa'da kadın işsizlik oranı \%8 iken, erkek işsizlik oranı ise \%7.4; Doğu Avrupa'da ise kadın işsizlik oranı \%4.9 iken, erkek işsizlik oranı ise \%5.5'tır (ILO, 2019:20-111-113).

Tablo 1. AB'de İşsizliğin Cinsiyete Göre Genel Görünümü (\%)

\begin{tabular}{ccccc}
\hline Yaş & Y1l & Kadin & Erkek & Toplam \\
\hline \multirow{2}{*}{$15-24$} & 2002 & 20.2 & 18.8 & 19.4 \\
& 2018 & 15.7 & 16.5 & 16.1 \\
\hline \multirow{2}{*}{$15-64$} & 2002 & 10.8 & 8.8 & 9.7 \\
& 2018 & 7.7 & 7.1 & 7.4 \\
\hline
\end{tabular}

Kaynak: Eurostat

Avrupa İstatistik Ofisi (Eurostat) verilerine göre, işsizlik verilerinde bir artış olduğu görülmektedir. 2018 yılında toplam genç işsizlik oranı, 15-64 yaş arası toplam işsizlik oranının 2.2 katı, genç kadın işsizliği 
ise 15-64 yaş arası toplam kadın işsizlik oranının yaklaşık 2 katıdır. Genel olarak özetlemek gerekirse AB ülkelerinde genç işsizliği oldukça yüksek seviyelerde olup, genç kadınların erkeklere göre iş bulma olasılığı daha düşüktür.

AB ülkelerinde uzun dönemli işsizlik sorunu gençlerde yetişkinlere nazaran daha çok görülmektedir. Deneyimi olmayan genç bireylerin, uzun vadede işsiz olabilme riski doğal olarak çok yüksektir. Tecrübeli olan, önceleri sanayide çalışan, daha sonra işini kaybeden yaşlılar da uzun vadede farklı iş bulmada zorlanmaktadır. Farklı yaş grupları ile kıyaslandığında genç bireylerin uzun dönemli işsizlik tehlikesiyle karşılaşma olasılığı daha düşüktür. Genç bireylerin tecrübeleri az olduğundan ya da hiç olmadığından ücretleri düşüktür ve gençler işsizlik sigortasından yararlanamazlar. Gençlerin iş piyasasında daha fazla hareketliliğe sahip olduğunu da belirtmek gerekir. İstedikleri zaman bulundukları şehirden (ülkeden veya bölgeden) çok rahat ayrılabilirler. Yerleşmiş bir hayat tarzları olmadığından geçici ve/veya kısmi zamanlı işlerde çalışmayı tercih edebilirler. Söz konusu tercih, onların çok fazla iş imkanı bulmalarına yardımcı olur. Buna ilaveten, yetişkinlere kıyasla yeteneklerini artırmak ya da geliştirmek amacıyla eğitim almak için belirli bir süre iş piyasasında yer alamayabilir ve daha nitelikli bir işgücü olarak tekrar işgücü piyasasına dönebilmektedir (Duruel, 2007:384-385).

Ekonomik büyümenin artırılması her zaman işsizlik sorununun çözümüne yol açmamaktadır ki, bu durum literatürde "istihdamsız büyüme" olarak bilinmektedir. $\mathrm{Bu}$ nedenle, ülkeler genç işsizlikle mücadelede ulusal istihdam politikaları hazırlamalı veya mevcut politikaların etkinliği tartışılmalı ve güncellenmesi önem arz etmektedir. Bu kapsamda dünyada genel kabul görmüş politikalar "eğitim ve aktif işgücü politikaları"dır (Özcan vd., 2016:93).

Avrupa 2020 Stratejisi (2010-2020), 2010 yılında kabul edilip, akılcı ve sürdürülebilir bir büyüme için işgücü piyasasında 2020’ye kadar yetişkin bireylerin işgücü piyasasına katılımının \% 75 oranına çıkarmak en temel hedeflerden biridir. Ayrıca, istihdam politikaları kapsamında kadınlar ve erkeklerin işgücü piyasasına katılımının arttırılması, yapısal işsizliğin azaltılması ve iş kalitesinin arttırılması; işgücü piyasası ihtiyaçlarına cevap veren ve yaşam boyu öğrenmeyi teşvik eden yetenekli bir işgücü geliştirilmesi; her seviyede eğitim ve öğretim sistemlerinin kalitesini ve performansını artırma ve yüksek veya eşdeğeri eğitime katılımı artırma; sosyal içermeyi teşvik etme ve yoksullukla mücadele etme politikaları sayllabilmektedir (European Parliament, 2018a:14-15).

Genç işsizlik oranının \%25'in üzerinde olduğu bölgelerde eğitim, istihdam veya eğitim almayan gençleri desteklemek amacıyla Avrupa Sosyal Fonu bulunmaktadır. Bahsi geçen Fon, AB bütçesinden 3.2 milyar Euro kaynak ayrılarak Gençlik İstihdam Girişimi'ni desteklemektedir. 2007-2013 döneminde yaklaşık 10 milyon Avrupalıya iş imkanı sağlamada yardımcı olunmuştur. 2021-2027 arasındaki dönemde 101 milyar euroluk bir bütçe ayrılmıştır. Bu bütçe ile ekonominin ihtiyacına uyum sağlamak için eğitime ve becerilere (özellikle temel dijital beceriler) yatırım yapılması, özellikle işgücü piyasalarına entegrasyonu mümkün kılan eylemler yoluyla istihdamın teşvik edilmesi, özellikle de genç ve uzun süreli işsizlik oranları ve değişen iş biçimleriyle ilgili yeni sağlık risklerinin ele alınması planlanmaktadır (European Parliament, 2018b:3-4).

\subsection{AB'de Cinsiyet Eşitsizliği ile Mücadele Politikaları}

Birleşmiş Milletler Kalkınma Programı (UNDP, 2019a) tarafından ilan edilen 17 Sürdürülebilir Kalkınma Hedefleri'nden biri de toplumsal cinsiyet eşitliğidir. Kadınlar ve kız çocuklarının aleyhine yapılan her çeşit ayrımcılığın yok edilmesi sadece temel insan hakları için gerekli olmayıp, bununla birlikte sürdürülebilir kalkınmaya ivme kazandırmak için de kritik bir önem taşımaktadır. Kız çocukları ve kadınların güçlendirilmesinin çarpan etkisiyle ekonomik büyümeye ve her alanda gelişmeye hız kazandırdığg bilinmektedir. UNDP, 2000 yılından beri diğer Birleşmiş Milletler ve uluslararası toplum ortakları ile birlikte toplumsal cinsiyet eşitliği çalışmalarına ağırlık vermektedir. Günümüzde, on beş yıl öncesine oranla daha fazla sayıda kız çocuğu okula gitmekte; bölgelerin birçoğunda ilköğretimde cinsiyet eşitliğinin sağlandığ1 görülmektedir. Tarım sektörü dışındaki ücretli işgücünün \%41'ini kadınlar oluştururken, bu oran 1990 yılında \%35'tir. Bazı bölgelerin işgücü piyasasında devam eden büyük eşitsizlikler söz konusu olduğu gibi kadınlar, hala eşit iş imkanlarına sahip değildir. Cinsel sömürü ve şiddet, ücretsiz bakım ve ev işlerinin 
Eren, M. V. / Journal of Yasar University, 2020, 15/59, 598-614

eşit olmayan şekilde bölüşümü ve kamu görevlerinde yapılan ayrımcılık hala büyük engel teşkil etmektedir. Kadınlara, toprak ve mülk gibi ekonomik kaynaklara eşit haklar verilmesi, toplumsal cinsiyet eşitliği hedefinin gerçekleştirilmesinde hayati öneme sahiptir. Günümüzde kamuda çalışan kadın sayısı eskiye göre daha yüksek; fakat kadın liderlerin motivasyonun sağlanması, toplumsal cinsiyet eşitliği hedefini gerçekleştirecek politikaların etkinliğine ve mevzuatın güçlendirilmesine yardımcı olacaktır.

Avrupa Komisyonu 2015 yılında 2016-2019 cinsiyet eşitliği için stratejik sözleşmesini yayınlamış olup, beş öncelik alanına odaklanmıştır. Odak noktaları kadının işgücü piyasasına katılımını ve ekonomik bağımsızlığı arttırmak; cinsiyete dayalı ücret, kazanç ve emeklilik farklarını azaltmak ve böylece kadınlar arasında yoksullukla mücadele etmek; karar vermede kadınlar ve erkekler arasında eşitliği teşvik etmek; cinsiyete dayalı şiddetle mücadele etmek ve mağdurları korumak ve desteklemek; dünyada cinsiyet eşitliğini ve kadın haklarını teşvik etmek şeklinde sıralanmaktadır (European Parliament, 2018c:5).

Üye Devletlerdeki istihdam politikalarını koordine etmek için, asgari standartları belirlemek üzere bir Avrupa iş hukuku organı bulunmaktadır. Bu organ, kadınlar ve erkekler için işyerinde eşit muamele, hamilelik, doğum izni, ebeveyn izni konularında eşit firsatlar ile cinsiyet, 1rk, din, yaş, sakatlık ve cinsel yönelime dayalı ayrımcılığa karşı korunma hakkı sağlamaya çalışmaktadır (European Parliament, 2018d:3).

\section{Literatür Araştırması}

Cinsiyet eşitsizliği ile ekonomik büyüme/kalkınma arasındaki ilişkiyi araştıran birçok çalışma bulunmaktadır. Söz konusu çalışmalardan Klasen (1999), cinsiyet eşitsizliği ile ekonomik büyüme/kalkınma arasındaki ilişkiyi, Sahra altı Afrika ülkelerinde 1960-2012 dönemine ait verilerle EKK yöntemi kullanarak araştırmayı amaçlamıştır. Bahsi geçen amacı gerçekleştirmek için eğitimde ve istihdamda cinsiyet eşitsizliği, kişi başına milli gelir değişkenlerini modele dahil etmiştir. Çalışmadan ulaşılan sonuçlar, eğitim ve istihdamda cinsiyet eşitsizliği ile ekonomik büyüme arasında negatif yönlü iliş̧ki olduğunu göstermektedir. Ferrant (2011), Asya Ülkeleri için EKK yöntemi kullanarak cinsiyet eşitsizliği ile ekonomik büyüme arasındaki ilişkiyi, cinsiyet eşitsizliği ve kişi başına milli gelir değişkenlerini modele dahil ederek araştırmıştır. Cinsiyet eşitsizliği ile ekonomik kalkınma arasında negatif yönlü bir ilişkinin olduğu, analizden elde edilen sonuçtur. Ahang (2014), EKK yöntemiyle 2006-2012 dönemine ait verilerle gelişmiş ülkelerde ekonomik büyüme üzerinde cinsiyet eşitsizliğinin etkisini araştırdığı yapıtında, cinsiyet eşitliğinin kısa vadede ekonomik büyümede azalmaya yol açacağını, başka bir ifadeyle cinsiyet eşitliği ile ekonomik büyüme arasında negatif bir ilişki olduğunu ortaya çıkarmıştır. Khayria ve Feki (2015), cinsiyet eşitsizliği ile ekonomik kalkınma arasındaki ilişkiyi, 5 ülke örnekleminde 1985-2011 verileri yardımıyla araştırmayı konu edinmiştir. Çalışma kapsamında cinsiyet eşitsizliği, kişi başına milli gelir, yatırım/GSYİH, nüfus artış hızı değişkenleri ve GMM dinamik panel veri analizi yöntemi kullanılmıştır. Eserden elde edilen sonuç, cinsiyet eşitsizliği ile ekonomik büyüme ve yatırım arasında negatif yönlü bir ilişki varken, nüfus artışıyla pozitif yönlü bir ilişki vardır. Hakura vd. (2016) yaptıkları eserinde Sahra altı Afrika ülkelerine ait 1995-2014 dönemi verileriyle cinsiyet eşitsizliği ile ekonomik büyüme arasındaki ilişkiyi GMM ve dinamik panel veri analizi yöntemi yardımıyla analiz etmiştir. Analiz için cinsiyet eşitsizliği endeksi ve kişi başına milli gelir değişkenleri kullanılmış olup, cinsiyet eşitsizliği ile ekonomik büyüme arasında negatif yönlü bir ilişki olduğu sonucu elde edilmiştir. Tunç (2018), seçilmiş 99 ülke 2015 yılına ait verilerle yatay kesit analizi yöntemi kullanarak cinsiyet eşitsizliği ile kalkınma arasındaki ilişkiyi araştırmıştır. Araştırmayı gerçekleştirmek için insani kalkınma endeksi, toplumsal cinsiyet eşitsizliği endeksi, nüfus ve gini katsayısı değişkenlerini analize dahil etmiştir. Analiz sonuçları, farklı gelir düzeyine sahip ülkelerde kadın ayrımcılığı ile kalkınma arasında negatif yönlü ilişki olup, düşük gelir düzeylerindeki ülkelerde yüksek gelirlilere göre daha büyük etkisi olduğunu göstermiştir.

Ekonomik büyüme ve kalkınma ile işgücüne katılımda cinsiyet ayrımı yapılarak farklı değişkenlerle arasındaki ilişkileri araştıran farklı çalışmalar da literatürdeki yerini almaktadır. Luci (2009) araştırmasında 184 ülkede 1965-2004 yılları arasındaki veriler için kadının işgücü piyasasına katılımı ile ekonomik 
Eren, M. V. / Journal of Yasar University, 2020, 15/59, 598-614

büyüme arasındaki ilişkinin varlığını analiz etmiştir. Kadının işgücü piyasasına katılımı ve GSYİH değişkenleri kullanılmış ve EKK yöntemi ile çalışma hazırlanmıştır. Çalışmada ekonomik büyümenin kadın istihdamını negatif yönde etkilediği sonucu elde edilmiştir. Mujahid ve Zafar (2012), Pakistan'da 1980-2010 dönemi için kadının işgücüne katılımı ile ekonomik büyüme ilişkisini zaman serisi yöntemiyle araştırmıştır. Söz konusu çalışmada kişi başına düşen gelir ve kadının işgücüne katılımı değişkenleri kullanılmış olup, ARDL yaklaşımıyla tahmin edilmiştir. Çalışmadan elde edilen sonuç, değişkenler arasında uzun dönemli bir ilişki bulunmuştur. Ayrıca, ekonomik büyüme kadın istihdamını pozitif yönde etkilemektedir. Rakhis (2015), cinsiyet eşitsizliğinin ekonomik büyüme üzerindeki etkisini 19 Arap ülkesi için 1990-2014 dönemi verilerini kullanarak EKK yöntemi yardımıyla araştırmayı amaç edinmiştir. Çalışma için ekonomik büyüme, yatırımlar, kadın ve erkeklerin işgücüne katılım oranı, nüfus artış hızı değişkenleri analiz kapsamında değerlendirilmiştir. Analizden elde edilen sonuç, kadınların işgücüne katılımı ile büyüme arasındaki ilişki istatistiki olarak anlamsızken, erkeklerin işgücüne katılımı ile büyüme arasında ilişki pozitif yönlü olduğudur. Anyanwu (2016), genç istihdamda cinsiyet eşitliğini analiz ettiği çalışmasında, kişi başına düşen gelir, kadın nüfusunun oranı, ekonomik büyüme, kamu harcamalarının milli gelirden aldığı pay gibi birçok açıklayıcı değişkenle Afrika ve Sahra altı Afrika ülkeleri için 1991-2011 dönemi verilerini kullanmıştır. EKK yöntemine göre yapılan analizden elde edilen sonuçlara göre, genç istihdamda cinsiyet eşitliği ile kişi başına düşen gelir ve kamu harcamalarının milli gelirden aldığı pay arasında negatif bir ilişki varken, genç istihdamda cinsiyet eşitliği ile ekonomik büyüme ve kadın nüfusunun oranı arasında pozitif bir ilişki vardır.

Literatürdeki çalışmalar özetlendiğinde, cinsiyet eşitsizliği için toplumsal cinsiyet eşitsizliği endeksi ve işgücüne katılımda kadının payı değişkenleri ile yöntem olarak genellikle EKK metodu kullanılmıştır. Çalışmalardan elde edilen sonuç, kadının işgücüne katılımı ile ekonomik büyüme/kalkınma arasında pozitif bir ilişki bulunmaktadır. Bu çalışmada ise, yöntem olarak yatay kesit bağımlılığı ve nedensellik testi kullanıldığından diğer çalışmalardan ayrılmaktadır. Ayrıca çalışmalarda insani kalkınma endeksini (Tunç, 2018) ve genç kadın istihdam değişkenini (Anyanwu, 2016) kullanan birer çalışmaya rastlanılmaktadır. Bu çalışmalar dışında, genç ve kadın istihdamı ile insani kalkınma endeksini kullanan çalışmaya rastlanılmamıştır. Bu çalışmada ise diğer çalışmalardan farklı olarak istihdam verisi yerine işsizlik değişkeni analize dahil edilmiştir. Cinsiyet eşitliği için genç kadın ve genç erkek işsizliği değişkenleri kullanıldığından literatüre katkı yapması planlanmaktadır.

\section{Ekonometrik Analiz}

Çalışmanın analiz kısmında, cinsiyet eşitsizliği kapsamında genç kadın işsizliği ile kalkınma arasındaki ilişki Avrupa Birliği ülkeleri* üzerinden test edilmektedir. Bu kapsamda öncelikle kurulan modelde kullanılacak değişkenlere ait veri seti ve model tanıtılmakta, kullanılacak yöntem sunulduktan sonra elde edilen bulgular yorumlanmaktadır.

\subsection{Veri Seti, Model ve Yöntem}

Araştırmada, "genç kadın işsizliği ile kalkınma arasında ilişki vardır” şeklinde kurgulanan hipotez, 27 AB ülkeleri üzerinden 1991-2018 dönemlerine ait yıllık veriler kullanılarak ekonometrik testler ile analiz edilmektedir. Modele dahil edilen değişkenlerden kalkınma değişkeni olarak insani gelişme endeksi (HDI), bağımsız değişkenler olarak ise genç kadın işsizlik oranı (YUF) ve genç erkek işsizlik oranı (YUM) kullanılmıştır. Analizlerde kullanılan HDI değişkeni UNDP, diğer değişkenler ise Dünya Bankası (World Bank (a)) veri tabanından elde edilmiştir.

İnsani Gelişme Endeksi (HDI-İGE) insan gelişiminin üç temel boyutuna (doğumda beklenen yaşam süresi ile ölçülen uzun ve sağlıklı bir yaşam sürdürebilme; ortalama eğitim süresi ve beklenen eğitim süresi

\footnotetext{
* Brexit anlaşması nedeniyle İngiltere kapsam dışı bırakılmıştır.
} 
Eren, M. V. / Journal of Yasar University, 2020, 15/59, 598-614

ile ölçülen bilgi edinme yeteneği ve kişi başına gayri safi milli gelir ile ölçülen, iyi bir yaşam standardı yakalama yeteneği) odaklanan bir bileşik endekstir (UNDP, 2019b:300).

İnsani Gelişme Endeksi (İGE) değerleri ve dört insani gelişme kategorisindeki insan sayısı bakımından 1990-2018 arasındaki insani gelişme ilerlemesini yansıtmaktadır. Küresel nüfusun 1990 ve 2018 yılları arasında 5.3 milyardan 7.6 milyara çıkmasına rağmen, düşük insani gelişme düzeyindeki insan sayısının 3.3 milyardan 705 milyona veya dünya nüfusunun \%62'sinden \%9'una düştüğünü göstermektedir (World Bank (b)). 2019 yılındaki raporda, 2018 yılı için en yeni verilere sahip 189 ülke ve bölge için İGE değerlerini sunulmaktadır. Bu ülkelerden 62'si çok yüksek insani gelişme grubunda, 54'ü yüksek, 37'si orta ve 36'sı düşük insani gelişme grubundadır (UNDP, 2019b:300-303).

IGE değeri 0 ile 1 arasında bir değer almaktadır. Endeks değeri arttıkça insani gelişmişlik derecesi de artmaktadır. Ülkeler, endeks değerlerine göre sınıflandırılmaktadır (Berber, 2017:254). İGE, 0.000 ile 0.550 arasında ise düşük insani gelişmiş, 0.550-0.699 arasında ise orta insani gelişmiş, 0.700-0.799 arasında ise yüksek insani gelişmiş ve 0.800-1.000 arasında ise çok yüksek insani gelişmiş ülke sınıfında yer almaktadır (UNDP, 2019b:295). 2018 verilerine göre 27 AB ülkesi çok yüksek insani gelişmişlik düzeyinde yer almaktadır. En düşük endeks değerine sahip olan Romanya (0.816) iken, en yüksek endeks değerine sahip olan ülke ise Norveç (0.954)'tir (UNDP, 2019b:300).

Genç işsizlikte cinsiyet eşit(siz)liği ile kalkınma arasındaki ilişkinin incelendiği çalışmada, belirtilen örneklem ve veri aralığında kullanılan model şu şekilde kurgulanmıştır;

$$
H D I_{i t}=\beta_{0}+\beta_{1} Y U F_{i t}+\beta_{2} Y U M_{i t}+\varepsilon_{i t}
$$

Modelde gösterilen $\mathrm{i}=1,2,3, \ldots . \mathrm{N}$ yatay kesit verilerini gösterirken, $\mathrm{t}=1,2,3, \ldots . \mathrm{T}$ zaman boyutunu, $\varepsilon$ ise hata terimini ifade etmektedir.

Avrupa Birliği ülkeleri üzerinde genç kadın işsizliği ile kalkınma arasındaki ilişkinin incelendiği çalışmada panel veri analizi kullanılmış olup, uygulanan metodolojik sıralama şu şekildedir;

Değişkenlerin yatay kesit bağımlılığının varlığının analizi için Breusch-Pagan (1980)'ın CD ${ }_{\operatorname{lm} 1}$ ve Pesaran vd. (2008)'nin $\mathrm{LM}_{\mathrm{adj}}$ testi,

$>\quad$ Modele dahil edilen değişkenlerin birim kök içerip içermediği Pesaran (2007)'ın CADF durağanlık testi,

$>\quad$ Eğim katsayılarının birimler arasında değişip değişmediğinin tespiti için Pesaran ve Yagamata (2008)'nın geliştirdiği Delta testi,

$>\quad$ Modele dahil edilen değişkenler arasında eşbütünleşme ilişkisinin tespiti için Westerlund (2008)'un geliştirdiği Durbin-Hausman eşbütünleşme testi,

Eşbütünleşme testlerinden elde edilen sonuçların ardından eşbütünleşme katsayılarının tahmininde CCE ile AMG tahmincisi,

$>\quad$ Son olarak nedensellik testi için Dumitrescu-Hurlin (2012) panel nedensellik testi kullanılarak analizler gerçekleştirilmiştir.

\subsection{Ekonometrik Bulgular}

Panel veri analizleri yapılırken yatay kesit bağımlılığının test edilmesi önem arz etmektedir. Analizlerde kullanılan birim kök, eşbütünleşme ve nedensellik testlerinin birçoğu son zamanlarda yatay kesit bağımlılığına karşı duyarlı hale gelmektedir. Yatay kesit bağımlılığını dikkate almayan testler literatürde birinci nesil testler olarak bilinirken, yatay kesit bağımlılığını dikkate alan testler ise ikinci nesil testler olarak bilinmektedir. Bahsi geçen bağımlılık, panel veri modellerinde yer alan her bir ülke/bölge/şehir gibi kesitler için hesaplanan hata terimleri arasında korelasyonun varlığını belirtmektedir. Bu durum, kesitlerin birbirlerine bağımlı hale gelmesi veya kesitlerden birine gelen şokun diğer kesitleri etkilediği anlamına gelmektedir (Öncel vd., 2017:409).

Seriler arasında yatay kesit bağımlılığının varlığı; T>N (zaman boyutu yatay kesit boyutundan büyük) olduğunda Breusch-Pagan (1980) $\mathrm{CD}_{\operatorname{lm} 1}$ testiyle; $\mathrm{T}=\mathrm{N}$ (zaman boyutu, yatay kesit boyutuna eşit) olduğunda Pesaran (2004) $\mathrm{CD}_{\operatorname{lm} 2}$ testiyle; $\mathrm{T}<\mathrm{N}$ (zaman boyutu yatay kesit boyutundan küçük) olduğunda ise Pesaran (2004) CD testiyle kontrol edilmektedir. Breusch-Pagan (1980) LM testi, grup ortalaması sifir fakat bireysel 
ortalama sıfırdan farklı olduğunda sapmalı olmaktadır. Pesaran vd. (2008), bu sapmayı test istatistiğine varyansı ve ortalamayı da ilave ederek düzeltmiştir. Bu nedenle ismi, düzeltilmiş LM testi ( $\left.\mathrm{LM}_{\mathrm{adj}}\right)$ olarak ifade edilmektedir. Bu test, $\mathrm{N}>\mathrm{T}$ ve $\mathrm{T}>\mathrm{N}$ olduğunda kullanılabilmektedir.

Birimler arasında bağımlılığın olup olmadığını test etmek amacıyla yatay kesit bağımlılığı testi yapılmış, ilgili testin sonuçları Tablo 2'de görülmektedir.

Tablo 2. Yatay Kesit Bağımlılı̆̆ Testi Sonuçları

\begin{tabular}{|c|c|c|c|c|c|}
\hline Değişkenler & CD Testleri & $\begin{array}{c}\mathrm{CD}_{\operatorname{lm} 1} \\
(\mathrm{BP}, 1980)\end{array}$ & $\begin{array}{c}\mathrm{CD}_{\operatorname{lm} 2} \text { (Pesaran, } \\
2004)\end{array}$ & $\begin{array}{c}\text { CD } \\
\text { (Pesaran, 2004) }\end{array}$ & $\begin{array}{c}\mathrm{LM}_{\text {adj }} \text { (Pesaran vd., } \\
\text { 2008) }\end{array}$ \\
\hline \multirow{2}{*}{ HDI } & Test İstatistiği & 9240.835 & 335.5252 & 967.10040 & 335.0252 \\
\hline & Olasılık Değeri & $0.0000 *$ & $0.0000^{*}$ & $0.0000 *$ & $0.0000 *$ \\
\hline \multirow{2}{*}{ YUF } & Test Istatistiği & 1424.678 & 40.52335 & 16.75281 & 40.02335 \\
\hline & Olasılık Değeri & $0.0000 *$ & $0.0000^{*}$ & $0.0000 *$ & $0.0000^{*}$ \\
\hline \multirow{2}{*}{ YUM } & Test Ístatistiği & 1646.286 & 48.88741 & 19.73396 & 48.38741 \\
\hline & Olasılık Değeri & $0.0000 *$ & $0.0000 *$ & $0.0000 *$ & $0.0000 *$ \\
\hline
\end{tabular}

Not: ${ }^{*}$. ** ve $* * *$ serilerin sırasıyla $\% 1, \% 5$ ve $\% 10$ düzeyinde kesitler arasında bağımlılı̆̆ın olduğunu göstermektedir.

Yatay kesit bağımlılığı test sonuçlarının gösterildiği Tablo 2 incelendiğinde uygulanan tüm testlerin olasılık değerlerinin 0.05'ten küçük olduğu görülmektedir. Çalışmada, 1991-2017 yılları arasındaki dönemlerde incelendiği için, zaman boyutu gözlem boyutundan büyüktür. Analize dahil edilen ülke sayıs1 27 iken zaman boyutu ise 28 dir. $(\mathrm{T}>\mathrm{N})$ olduğundan $\mathrm{CD}_{\mathrm{LM} 1}$ ve $\mathrm{LM}_{\mathrm{adj}}$ sonuçlarına göre karar verilebilmektedir. Yatay kesit bağımlılığı testlerinde $\mathrm{CD}_{\mathrm{LM} 1}$ testi genellikle sapmalı sonuçlar verebildiğinden dolayı $\mathrm{LM}_{\mathrm{adj}}$ testi sonuçları dikkate alınmaktadır. $\mathrm{LM}_{\mathrm{adj}}$ testi sonuçlarına göre, temel hipotez olan "ülkeler arasında yatay kesit bağımlılığı yoktur" kuramı reddedilerek, panel veride yer alan “ülkeler arasında yatay kesit bağımlılığı bulunmaktadır” hipotezi kabul edilir. Değişkenlerde yatay kesit bağımlılığının tespit edilmesinden dolayı bundan sonra uygulanacak testlerde ikinci nesil testler tercih edilmektedir.

$\mathrm{Bu}$ durum günümüz küresel dünyası ile de uyumlu olup, $\mathrm{AB}$ ülkelerinden birine gelebilecek bir şok etkisi, AB üyesi diğer ülkeleri de etkileyebileceği sonucu çıkarılmaktadır. Bu nedenle, gerek AB ülkelerinin geleceğini kurgulayan politikacılar gerekse de her bir $\mathrm{AB}$ ülkesinin yöneticisi, kendi politikalarını geliştirirken bu durumu dikkate alarak geleceğe yön vermesi gerekmektedir.

Birimler (kesitler) arasında bağımlılık olan değişkenlerin birim kök testi analizinde tutarlı ve sapmasız sonuçlar elde edilmek amacıyla ikinci nesil birim kök testlerinin kullanılması gerekmektedir. İkinci nesil birim kök testlerinden Pesaran (2007) tarafından geliştirilen CADF birim kök testi, araştırmaya dahil edilen bütün ülkeler için ayrı ayrı durağanlık sonuçlarını göstermektedir. CADF testi ile değişkenlerin durağanlığını, panelin geneli ve her bir ülke için ayrı ayrı tespit etmek mümkündür. CADF testinin bir başka özelliği ise, mekansal otokorelasyonu dikkate alarak, $\mathrm{T}>\mathrm{N}$ ve $\mathrm{N}>\mathrm{T}$ durumunda kullanılabilmektedir.

Tablo 3. CADF Birim Kök Testi Sonuçları

\begin{tabular}{lcccc}
\hline Ülke & HDI & YUF & YUM & $\Delta$ HDI \\
\hline Avusturya & $-6.642(2)^{*}$ & $-3.630(2)^{* * *}$ & $-2.929(2)$ & $-6.102(2)^{*}$ \\
Belçika & $-7.680(2)^{*}$ & $-3.500(2)^{* * *}$ & $-1.287(3)$ & $-5.493(2)^{*}$ \\
Bulgaristan & $-2.721(2)$ & $3.978(2)^{* *}$ & $-3.006(2)$ & $-5.127(2)^{*}$ \\
Hirvatistan & $-1.799(2)$ & $-3.191(2)$ & $-3.269(2)$ & $-4.654(2)^{* *}$ \\
Kibris & $-1.636(2)$ & $-4.048(2)^{* *}$ & $-3.045(2)$ & $-5.173(2)^{*}$ \\
Çek Cumhuriyeti & $-1.072(5)$ & $-3.830(2)^{* * *}$ & $-3.320(2)$ & $-4.360(2)^{* *}$ \\
Danimarka & $-2.098(2)$ & $-3.447(2)$ & $-2.343(2)$ & $-4.876(2)^{*}$ \\
Estonya & $-1.851(2)$ & $-2.971(2)$ & $-2.161(2)$ & $-4.377(2)^{* *}$ \\
Finlandiya & $-1.400(2)$ & $-2.165(2)$ & $-1.692(2)$ & $-3.459(2)$ \\
Fransa & $-1.183(2)$ & $-2.113(2)$ & $-1.211(2)$ & $-2.931(2)$ \\
Almanya & $-1.509(2)$ & $-2.691(2)$ & $-1.942(2)$ & $-4.472(2)^{* *}$ \\
Yunanistan & $-1.487(2)$ & $-3.696(2)^{* * *}$ & $-3.247(2)$ & $-3.814(2)^{* * *}$
\end{tabular}


Eren, M. V. / Journal of Yasar University, 2020, 15/59, 598-614

\begin{tabular}{|c|c|c|c|c|}
\hline Macaristan & $-1.967(2)$ & $-3.219(2)$ & $-3.304(2)$ & $-2.617(2)$ \\
\hline İrlanda & $-2.173(2)$ & $-3.406(2)$ & $-3.883(2)^{* *}$ & $-2.462(2)$ \\
\hline İtalya & $-2.326(2)$ & $-3.606(2)^{* * *}$ & $-3.465(2)$ & $-3.872(2) * * *$ \\
\hline Letonya & $-1.964(2)$ & $-3.077(2)$ & $-3.297(2)$ & $-3.482(2)$ \\
\hline Litvanya & $-2.055(2)$ & $-2.864(2)$ & $-2.640(2)$ & $-3.264(2)$ \\
\hline Lüksemburg & $-1.711(2)$ & $-2.652(2)$ & $-2.925(2)$ & $-2.312(2)$ \\
\hline Malta & $-1.561(2)$ & $-3.479(2)$ & $-3.249(2)$ & $-3.631(2)^{* * *}$ \\
\hline Hollanda & $-1.644(2)$ & $-3.166(2)$ & $-3.155(2)$ & $-3.899(2)^{* *}$ \\
\hline Polonya & $-1.772(2)$ & $-3.292(2)$ & $-2.846(2)$ & $-4.739(2)^{*}$ \\
\hline Portekiz & $-1.625(2)$ & $-3.884(2)^{* *}$ & $-2.991(2)$ & $-4.817(2)^{*}$ \\
\hline Romanya & $-0.773(2)$ & $-4.105(2) * *$ & $-3.105(2)$ & $-3.454(2)$ \\
\hline Slovakya & $-0.338(2)$ & $-3.601(2) * * *$ & $-2.528(2)$ & $-3.574(2)^{* * *}$ \\
\hline Slovenya & $-0.066(2)$ & $-3.411(2)$ & $-1.752(2)$ & $-3.783(2) * * *$ \\
\hline İspanya & $-1.299(2)$ & $-3.600(2)^{* * *}$ & $-3.000(2)$ & $-4.697(2)^{*}$ \\
\hline İsveç & $-3.083(2)^{* * *}$ & $-3.695(2) * * *$ & $-3.491(2) * * *$ & $-5.005(2)^{*}$ \\
\hline CIPS istatistiğ $i$ & -2.053 & $-3.345^{*}$ & $-2.781^{* *}$ & $-4.091^{*}$ \\
\hline
\end{tabular}

Tablo 3'te değişkenlerin düzey ve fark değerlerinde paneli oluşturan ülkelerin her biri için CADF ve panelin geneli için CIPS birim kök testi sonuçları gösterilmektedir. Test sonuçlarına göre, bazı ülkelere ait değişkenlerin düzey değerinde birim köklü iken, bazılarında ise birim köklü değildir. Panelin geneline bakıldığında, HDI değişkeni dışındaki değişskenler düzey değerlerinde durağandır. HDI değişkeninin birim kök sorununu çözebilmek amacıyla birinci farkı alınarak test tekrar uygulanmakta ve sonuca yeniden bakılmaktadır. HDI değişkeninin birinci farkı alınarak test yeniden uygulandığında değişkenin durağan hale geldiği görülmektedir. Başka bir ifadeyle, HDI değişkeni I(1) iken, diğer değişkenler I(0) olup, analize dahil edilen değişkenler farklı mertebelerde durağandır.

Panel veri analizi yapılan çalışmalar için paneldeki birimlere ait eğim katsayılarının birimler arasında değişip değişmediğinin tespiti, değişkenler arasındaki uzun dönemli ilişkinin saptanması açısından önem arz etmektedir. Pesaran ve Yamagata (2008)'nın literatüre kazandırdığı Delta testi ile yatay kesitlerin (ülkelerin) eğim katsayılarının bütün birimler için sabit olması (homojen) ve birimler arasında değiştiği (heterojen) araştırılmaktadır. Bahsi geçen test uygulandığında iki test istatistiği elde edilmektedir.

Tablo 4. Homojenite Testi Sonuçları

\begin{tabular}{lcc}
\hline Test istatistiği & T istatistiği & Olasılık Değeri \\
\hline Delta_tilde & 21.731 & $0.000^{*}$ \\
Delta_tilde_adj & 23.405 & $0.000^{*}$ \\
\hline
\end{tabular}

Not: *,** ve *** sırasıyla \%1, \%5 ve \%10 anlamlılık düzeyinde eğim katsayılarının heterojen olduğunu göstermektedir.

Genç kadın işsizliği ile kalkınma arasındaki ilişkinin analiz edildiği çalışmada kurulan modele göre eğim katsayılarının birimler arasında değişip değişmediğinin tespiti için Delta homojenite testi gerçekleştirilmiş olup elde edilen bulgular Tablo 4'te gösterilmiştir. Test sonuçlarına göre her iki test istatistiğinin olasılık değerinin 0.05 'ten küçük olduğu için uzun dönemde birimler arasında eğim katsayılarının değiştiği, bu nedenle değişkenlerin heterojen olduğu sonucuna ulaşılmıştır. Değişkenlerin heterojen olmasından dolayı değişkenler arası ilişkilerin analizinde grup istatistiklerinin kullanılması gerekmektedir.

Bağımlı değişkenin birinci mertebeden [I(1)] durağan olması şartıyla açıklayıcı değişkenlerin farklı derecelerden (I(0) veya $\mathrm{I}(1)$ ) durağan olması durumunda eşbütünleşme analizinin yapılmasına imkan veren Westerlund (2008)'un Durbin-Hausman eşbütünleşme testi yardımıyla değişkenler arasındaki uzun dönemli ilişkinin varlığı araştırılmıştır. Test sonucunda panel ve grup olmak üzere iki istatistik hesaplanmakta olup, eğim katsayılarının birimler arasında değişmesi durumunda grup istatistiği; değişmemesi durumunda ise panel istatistiği göz önünde bulundurulmuştur. 
Eren, M. V. / Journal of Yasar University, 2020, 15/59, 598-614

Tablo 5. Durbin-Hausman Eşbütünleşme Testi Sonuçları

\begin{tabular}{lcc}
\hline Test istatistiği & İstatistik Değeri & Olasıllk Değeri \\
\hline Durbin-H Grup İstatistiği & 781.872 & $0.000^{*}$ \\
Durbin-H Panel İstatistiği & 65.619 & 0.000 \\
\hline Not: ${ }^{* * *}{ }^{* *}{ }^{* * *}$ sırasılyla $\% 1, \% 5$ ve \%10 anlamlılık düzeyinde değişkenler arasında uzun dönemli ilişkinin olduğunu göstermektedir.
\end{tabular}

Tablo 5 'te görüleceği üzere, eğim katsayılarının değiştiği ve değişkenlerin heterojen olduğu modelde, değişkenler arasındaki uzun dönemli ilişkinin tespiti için ikinci nesil ekonometrik testlerden DurbinHausman eşbütünleşme testi kullanılmıştır. Homojenite testinden elde edilen sonuçlar incelendiğinde, grup istatistiklerinin kullanılmasının daha uygun olacağı tespit edildiğinden, Durbin-H Grup istatistiği sonuçları dikkate alınmaktadır. Durbin-H Grup istatistiğinin olasılık değerleri incelendiğinde 0.01 'dten küçük olmasından dolayı değişkenler arasında uzun dönemli bir ilişkinin olduğu sonucuna ulaşılmaktadır.

Genç kadın işsizliği ve genç erkek işsizliği ile kalkınma arasında uzun dönemli ilişkinin tespit edilmesinden dolayı, modelde bağımsız değişken olarak tanımlanan YUF ve YUM'ın katsayı tahminlerinin yapılması gerekmektedir. Çalışmada panel eşbütünleşme katsayı tahmincisi olarak eğim katsayılarının birimler arasında değiştiği durumlarda yapılabilen CCE ve AMG tahmincisi kullanılmıştır.

Pesaran (2006)'ın geliştirdiği CCE (Common Correlated Effects: Ortak İlişkili Etkiler) yönteminde panelin geneli için bağımsız değişkenlerin katsayısı, birimlere ait katsayıların aritmetik ortalaması alınarak hesaplanmaktadır. Eberhardt ve Bond (2009)'un literatüre kazandırdığı AMG metodunda ise, birimler arasındaki bağımlılık göz önünde bulundurulurken, aynı zamanda panelin geneline ait sonuç ve bireysel katsayılar ağırlıklandırılarak ortalama grup etkisi hesaplanmaktadır. CCE ve AMG yöntemleri, heterojen panel veri modellerinin tahmininde kullanılabilmektedir.

Tablo 6. Panel Eşbütünleşme Katsayıları Tahmin Sonuçları

\begin{tabular}{l|ccc|ccc}
\hline & \multicolumn{3}{|c|}{ CCE Tahmincisi } & \multicolumn{3}{c}{ AMG Tahmincisi } \\
\hline Bağı̆msız & \multirow{2}{*}{ Katsayı } & Standart Hata & $\begin{array}{c}\text { Olasılık } \\
\text { Değeri }\end{array}$ & \multirow{2}{*}{ Katsayı } & Standart Hata & $\begin{array}{c}\text { Olasılık } \\
\text { Değeri }\end{array}$ \\
Değişkenler & & & 0.688 & 0.0000442 & 0.0001707 & 0.796 \\
YUF & 0.0000744 & 0.000185 & 0.000156 & 0.806 \\
\hline YUM & -0.00000528 & 0.0001717 & 0.975 & 0.0000384 & 0.000156 \\
\hline$* * * * *$
\end{tabular}

Tablo 6'da katsayı tahmincisi olarak kullanılan CCE ve AMG testlerinin sonuçları kontrol edildiğinde her ikisinin de birbiriyle uyumlu olduğu görülmektedir. Bağımsız değişkenler ile bağımlı değişken olarak belirlenen kalkınma arasındaki ilişkilerin katsayılarının olasılık değerlerinin istatistiki olarak anlamlı olmadığ 1 görülmektedir.

Değişkenler arasındaki nedensellik ilişkisinin araştırılmasında çalışmanın amacına yönelik olarak Dumitrescu ve Hurlin (2012) tarafından geliştirilen nedensellik testi kullanılmıştır. Bu yöntemi diğer nedensellik testlerinden ayıran özelliği, paneli oluşturan ülkeler arasındaki hem yatay kesit bağımlılığını hem de heterojenliği göz önünde bulundurabilmesi, $N>T$ ve $T>N$ olduğunda da kullanılabilmesi ve dengesiz panel veri setlerinde de etkin sonuçlar verebilmesidir. Dumitrescu ve Hurlin testinin bir diğer özelliği ise eşbütünleşme ilişkisinin olmadığı veya araştırılamadığı durumda da analiz yapabilmesidir. Bu çalışmada Dumitrescu-Hurlin panel nedensellik testi ile nedensellik ilişkilerinin varlığı araştırılmıştır.

Tablo 7. Dumitrescu-Hurlin Nedensellik Testi Sonuçları

\begin{tabular}{llcc}
\hline Nedenselliğin Yönü & Test & Test İstatistĭ̆ & Olasıllk Değeri (\%10) \\
\hline \multirow{2}{*}{$\Delta$ HDI $\neq>$ YUF } & Z-bar & 9.4711 & 0.2902 \\
& Z-bar tilde & 0.5674 & 0.4575 \\
\hline \multirow{2}{*}{ YUF $\neq>\Delta$ HDI } & Z-bar & 15.1384 & $0.0837^{*}$ \\
& Z-bar tilde & 1.6427 & $0.0837^{*}$ \\
\hline \multirow{2}{*}{$\Delta$ HDI $\neq>$ YUM } & Z-bar & 10.1859 & 0.2408 \\
& Z-bar tilde & 0.7030 & 0.3460 \\
\hline YUM $\neq>$ HDI & Z-bar & 6.6891 & 0.5792 \\
\hline
\end{tabular}


Eren, M. V. / Journal of Yasar University, 2020, 15/59, 598-614

Z-bar tilde

0.0395

0.9506

Not: *, \%10 anlamlılık düzeyinde değişkenler arasında nedenselliğin olduğunu göstermektedir. $\neq>$ simgesi nedenselliğin yönünü göstermektedir. Test istatistikleri 789 yineleme ile elde edilmiştir.

Cinsiyet eşitsizliği ile kalkınma arasındaki ilişkinin araştırıldığı çalışmada, Dumitrescu-Hurlin nedensellik testi kullanılmış olup, elde edilen bulguların sonuçları Tablo 7'de verilmiştir. Tablo incelendiğinde genç kadın işsizliğinden kalkınmaya doğru tek yönlü nedensellik ilişkisi olduğu görülmektedir. Diğer değişkenler arasında herhangi bir nedensellik ilişkisi tespit edilememiştir. Başka bir ifadeyle belirtmek gerekirse, genç erkek işsizliği ile kalkınma arasında herhangi ilişki yoktur. Genç erkek işsizliğinin boyutunun kalkınmayı etkileyebilecek boyutta olmadığı anlaşılmaktadır.

\section{Sonuc}

Ülkelerin gelişmişlik düzeyi farklılık gösterse de kadınlar, çalışma hayatı başta olmak üzere hayatın her alanında ayrımcılıkla karşı karşıya kalmaktadır. Özellikle geleneksel toplumlarda kadınların üstlendiği roller genellikle aile kurumu üzerine odaklandığından, işgücüne katılımda erkeklerin oranı kadınlara göre daha yüksektir. Yani, çalışma hayatında erkeklerin yeri daha büyüktür. Bu durum, gelişmişlik düzeyi daha yüksek olan toplumlarda kadınların lehine çevrilmeye çalışılsa da erkeklerin önceliği söz konusudur. Çalışma saatleri, tam zamanlı çalışma, ücret düzeyleri, özlük hakları gibi unsurlar bakımından eşitliği sağlayabilen ülkelerin, sürdürülebilir kalkınmada önemli mesafe kaydettiği ifade edilmektedir. Kadın istihdamının artması veya işsizliğinin azalması, atıl kalan üretim faktörünün üretime katılarak büyümeye katkı sağlaması anlamına gelmektedir. Söz konusu kadın işsizliği gençler arasında arttığında eğitimli, yetenekli, istekli olan bireylerin işgücü piyasasından geri çekilmelerine yol açabilmektedir ki, bu durum yoksulluğun artmasına neden olabilmektedir. Dolayısıyla sürdürülebilir kalkınma sürecinde toplumsal cinsiyet eşitliğinin sağlanması önem arz etmektedir.

$\mathrm{Bu}$ çalışmada, Avrupa Birliği ülkeleri üzerine genç kadın işsizliği ile kalkınma arasındaki ilişkiyi araştırmak için 1991-2018 verileri yardımıyla panel veri analizi yapılmıştır. Analiz kapsamında yatay kesit bağımlılığ 1 testi yapılmış ve birimler arasında bağımlılığın olduğu görülmüştür. Yatay kesit bağımlılığı tespit edildiğinden, ikinci nesil testler kullanılmıştır. İkinci nesil birim kök testlerinden CADF ve CIPS testine göre, sırasıyla ülkeler ve panelin geneli bazında değişkenlerin farklı derecelerden durağan olduğu tespit edilmiştir. Ardından, uzun dönemli ilişkinin tespiti için Westerlund'un Durbin-Hausman eşbütünleşme testi uygulanmış ve değişkenler arasında uzun dönemli bir ilişki olduğu sonucuna ulaşılmıştır. Eşbütünleşme ilişkisinin varlığı ile birlikte katsayı tahmini yapılmış ve bağımsız değişkenlere ait katsayılar istatistiki olarak anlamlı olmadığı sonucuna ulaşılmıştır. Son olarak, Dumitrescu-Hurlin nedensellik testi uygulanmıştır. Söz konusu testten elde edilen sonuçlara göre, AB'de genç kadın işsizliğinden kalkınmaya doğru tek yönlü nedensellik ilişkisi bulunmuştur. Diğer değişkenler arasında herhangi bir nedensellik ilişkisi tespit edilememiştir. Nitekim bu durum, çalışmanın hipotezinin kabul edildiği anlamını taşımaktadır. Genç erkek işsizliği ile kalkınma arasında bir ilişkinin bulunamamasının nedenleri olarak erkeklerin yüksek ücretler istemesi, sahip olduğu niteliklere uygun iş araması ve bu sürenin uzaması veya verimli olmadığı alanlarda çalışması, aldığı eğitimlerin iş bulma sürecinde yetersiz kalması gibi nedenler sayılabilmektedir. Genç kadın işsizliği ile kalkınma arasında ilişkinin bulunması ise, genç kadınların erkeklere göre daha düşük ücretlerle çalışabilmesi, özellikle hizmet sektöründe tercih edilmesi, esnek çalışma saatlerini kabul etmesi gibi nedenlerle açıklanabilmektedir.

Cinsiyet eşitsizliği ile kalkınma arasındaki ilişkinin bulunduğu bu çalışma, Rakhis (2015)'in dışındaki diğer çalışmanın sonuçları ile örtüşmektedir. Rakhis (2015)'in çalışmasında kadınların işgücüne katılımı ile büyüme arasındaki ilişki istatistiki olarak anlamsız, erkeklerin işgücüne katılımı ile büyüme arasında ilişki istatistiki olarak anlamlı olduğundan, elde edilen sonuçlarla çelişmektedir. Bu çelişki, kullanılan değişkenlerin, yöntemin, veri aralığının ve ülke/ülke grubunun farklı olmasından kaynaklanabilmektedir.

Özetlemek gerekirse, bu çalışmadan elde edilen sonuç, Avrupa Birliği’nde genç kadınların kalkınma sürecinde önemli bir aktör olduğudur. Avrupa Birliği'nde cinsiyet eşitsizliğini gidermek amaciyla uygulanan politikaların sonuç vermeye başladığını göstermektedir. Ancak, genç kadın işsizliği, erkek 
işsizliğine göre eskiye nazaran aradaki fark azalsa da hala yüksektir (Tablo 1). Sorun, sadece genç kadın ve genç erkek işsizliği arasındaki farkın olması değildir. Bununla birlikte, gençlerin işsizlik sorunuyla karşı karşıya gelmeleridir. İşsizlik sorunu, gençlerin geleceğe umutsuz bakmalarına, işgücü piyasasından çekilmelerine, edindiği bilgileri zamanla kaybetmelerine, statü kaybı yaşamalarına, kötü alışkanlıklar edinmelerine neden olabilmektedir. Genç işsizlerin istihdam edilerek üretim faaliyetinde bulunmaları durumunda elde edilebilecek gelir, işsizliğin ekonomik maliyetini oluşturmaktadır. $\mathrm{Bu}$ nedenle, uygulanması gereken politikalar, hem genç işsizlikte cinsiyet ayrımcılığını hem de genç işsizliği ortadan kaldırmayı hedeflemelidir. Bahsi geçen hedefler için, yatırımların artırılması, yeni istihdam alanlarının açılması, ekonomik büyümenin hız kazanması, eğitimin daha nitelikli ve piyasaya yönelik olması gerekmektedir. Hükümetler, aktif istihdam politikaları uygulamalı ve istihdamsız büyüme sorununu çözecek reformlar yapmalıdır. Genç erkeklerin ve kadınların verimli olacağ 1 alanlarda çalışabileceği iş imkanlarının oluşturulması üzerinde durulması gereken konuların başında gelmektedir. Cinsiyete dayalı ücret, hak ve özgürlük farklarını azaltıcı projelere destekler verilmeli, bu desteklerin maddi imkanları ve toplumun ayrımcılığa karşı olan hassasiyeti artırılmalıdır. Yoksulluk sorununun çözümü ve sürdürülebilir kalkınmanın gerçekleştirilmesi için toplumsal cinsiyet eşitliğinin sağlanması önem arz etmektedir.

$\mathrm{Bu}$ çalışmanın, sürdürülebilir kalkınma sürecinde etkili olan cinsiyet eşitliği kapsamında genç işsizlik dışında farklı değişkenlerin tercih edildiği ve farklı yöntemlerin/ülkelerin kullanıldığı araştırmalara 1şık tutacağı düşünülmektedir. Ayrıca, cinsiyet eşitsizliği endeksi, işgücüne katılım oranı veya istihdam oranı, doğurganlık oranı gibi değişkenlerin kalkınma sürecinde önemli bir faktör olup olmadığı bundan sonraki araştırmalarda kullanılabilir. 
Eren, M. V. / Journal of Yasar University, 2020, 15/59, 598-614

\section{KAYNAKÇA}

Açıkgöz, F. (2017). "Seçilmiş Ülke Uygulamarında Genç İstihdamına Yönelik Aktif İşgücü Politikaları Ve İşkur İçin Öneriler”. Uzmanlık Tezi, Çalışma ve Sosyal Güvenlik Bakanlığı Türkiye İş Kurumu Genel Müdürlüğü, Ankara.

Ahang, M. (2014). "The impact of Gender inequality on Economic Growth in Developed Countries". The Accounting, Economics and Financial Management Conference, 26-27 October 2014, Tehran, Iran.

Aina, O. I. (2011). "Promoting Gender Equality for Sustainable Development". Social Development and Gender Empowerment, Ekiti State, Adetiloye Hall, Trade Fair Complex, Ado - Ekiti (November, 2011).

Alper, A. E. ve Oransay, G. (2015). "Cari Açık ve Finansal Gelişmişlik İlişkisinin Panel Nedensellik Analizi Ekseninde Değerlendirilmesi”. Uluslararası Ekonomi ve Yenilik Dergisi, 1(2), 73-85.

Anyanwu, J. C. (2016). "Analysis Of Gender Equality In Youth Employment In Africa". Allied Social Science Associations (ASSA) Convention, San Francisco, 3-5 January 2016.

Aytaç, S. (2018). "Kadınlara Yönelik Sosyal Politikalar". (Ed. Aysen Tokol ve Yusuf Alper) Sosyal Politika, 9. Bask1, Bursa: Dora Yayıncılık, ss.327-354.

Berber, M. (2017). İktisadi Büyüme ve Kalkınma. 6.Bask1, Trabzon: Celepler Matbaacıllı.

Breush, T. S. ve Pagan, A. R. (1980). "The Lagrange Multiplier Test and its Applications to Model Specification in Econometrics". The Review of Economic Studies, 47(1), 239-253.

Cenger, H. ve Çütcü, İ. (2018). "İthalattaki Değişimin Genç İşsizliğe Etkisi: Türkiye Ekonomisi Üzerine Ekonometrik Bir Uygulama”. Uluslararası Toplum Araştırmaları Dergisi, 8(Gençlik Araştırmaları Özel Say1s1), 485-503.

Dumitrescu, E.-I. ve Hurlin, C. (2012). "Testing for Granger non-causality in Heterogeneous Panels". Economic Modelling 29, 1450-1460.

Durgun, C. ve Gök, G. O. (2017). “Toplumsal Cinsiyet Eşitsizliği Bağlamında BRICS \& G7 Ülkelerinin Karşılaştırmalı Analizi”. BUJSS, 10(2), 20-32.

Duruel, M. (2007). “Avrupa Birliği'nde Uzun Dönemli İşsizliğe Karşı Uygulanan İstihdam Politikaları”. Sosyal Siyaset Konferanslarl Dergisi, (53), 375-421.

Eberhardt, M. ve Bond, S. (2009). “Cross-section Dependence in Nonstationary Panel Models: A Novel Estimator”, MPRA (Munich Personal RePEc Archive), Paper No: 17692.

European Parliament. (2018a). "Social and employment policy. European Union", http://www.europarl.europa.eu/RegData/etudes/PERI/2017/600416/IPOL_PERI(2017)600416_EN .pdf (05.02.2019).

European Parliament. (2018b). "European Social Fund, European Union", http://www.europarl.europa.eu/ftu/pdf/en/FTU_2.3.2.pdf (05.02.2019).

European Parliament. (2018c). "Equality Between Men and Women, European Union", http://www.europarl.europa.eu/ftu/pdf/en/FTU_2.3.8.pdf (05.02.2019).

European Parliament. (2018d). "Employment Policy, European Union”, http://www.europarl.europa.eu/ftu/pdf/en/FTU_2.3.3.pdf (05.02.2019).

Eurostat, "Unemployment Rates by Sex, Age and Citizenship (\%)", https://appsso.eurostat.ec.europa.eu/nui/show.do (24.02.2020)

Ferrant, G. (2011). "How Gender Inequalities Hinder Development: Cross-Country Evidence". CES Working Papers, pp.1-33.

Gündoğan, N. (1999). “Genç işsizliği ve Avrupa Birliği’ne Üye Ülkelerde Uygulanan Genç İstihdam Politikaları”. Ankara Üniversitesi Siyasal Bilgiler Fakültesi Dergisi, 1(54), 63-79.

Hakura, D., Hussain, M., Newiak, M., Thakoor, V. ve Yang, F. (2016). "Inequality, Gender Gaps and Economic Growth: Comparative Evidence for Sub-Saharan Africa". IMF Working Paper, $\mathrm{WP} / 16 / 111$. 
Eren, M. V. / Journal of Yasar University, 2020, 15/59, 598-614

ILO. (2018). "World Employment Social Outlook: Trends for Women 2019". https://www.ilo.org/wcmsp5/groups/public/---dgreports/---dcomm/--publ/documents/publication/wcms 670542.pdf (24.02.2020).

ILO. "Share of Youth not in Employment, Education or Training (youth NEET rate)". https://www.ilo.org/ilostat-files/Documents/description_NEET_EN.pdf (30.01.2019).

İnce Yenilmez, M. (2017). "Female Labor Force Participation in Turkey: GMM Evidence". I Ig $d \imath r$ Üniversitesi Sosyal Bilimler Dergisi, (13), 321-354.

Jacobsen, J. P. (2011). "Gender Inequality. Assessment Paper, Copenhagen Consensus on Human Challenges", https://www.copenhagenconsensus.com/sites/default/files/gender.pdf (04.02.2019).

Khayria, K. ve Feki, R. (2015). "Gender Inequality and Economic Development". Business and Economics Journal, 6(4), 1-3.

Kırkpınar, N. (2016). “Avrupa Birliği Ve Türkiye’de Kadinin Ekonomik Hayattaki Yeri”. Karatahta Işs Yazllar Dergisi, (4), 67-90.

Klasen, S. (1999). "Does Gender Inequality Reduce Growth and Development? Evidence from CrossCountry Regressions”. Policy Research Report On Gender And Development, Working Paper Series, No. 7.

Luci, A. (2009). "Female Labour Market Participation and Economic Growth". Int. J. Innovation and Sustainable Development, 4(2/3), 1-12.

Montiel, A. V. (2018). "Gender Equality and Big Data In The Context Of The Sustainable Development Goals". PACO (PArtecipazione e COnflitto), 11(2), 544-556.

Mujahid, N. ve Zafar, N. uz (2012). "Economic Growth-Female Labour Force Participation Nexus: An Empirical Evidence for Pakistan". The Pakistan Development Review, 51(4), 565-586.

Nasıroğlu, M. (2017). "Tarihten Dışlanmak: Tarihyazımında Kadın Etkinliğinin Dolaylı Yollardan Saptanmas1 Üzerine”. Social Sciences Studies Journal, 3(12), 2243-2251.

Nwogwugwu, N. ve Irechukwu, G. N. (2015). "Socio-Political Implications of Youth Unemployment on Nigeria's Economic Development”. IOSR Journal of Economics and Finance (IOSR-JEF), 6(4), 2734.

O'Higgins, N. (1997). "The challenge of youth unemployment”. Employment and Training Papers 7, Employment and Training Department, International Labour Office, Geneva.

Öncel, A., Kırca, M. ve İnal, V. (2017). "Elektrik Tüketimi ve Ekonomik Büyüme İlişkisi: OECD Ülkelerine Yönelik Zamanla Değişen Panel Nedensellik Analizi”. Maliye Dergisi, Temmuz-Aralık, (173), 398-420.

Özcan, P. M., Tepekule, U. ve Kayalıdere, G. (2016). "Eğitim Kalitesinin Genç İşsizliği ile İlişkisi: PISA Test Sonuçları Üzerinden Bir Değerlendirme”. Aydın İktisat Fakültesi Dergisi, 1(2), 89-113.

Özdemir, Z., Yalman, İ. N. ve Bayrakdar, S. (2012). "Kadın İstihdamı ve Ekonomik Kalkınma: Geçiş Ekonomileri Örneği”. International Conference on Eurasian Economies, 11-13 October, Almaty Kazakhstan.

Pesaran, M. H. (2004). “General Diagnostic Tests for Cross Section Dependence in Panels”. CWPE 0435.

Pesaran, M. H. (2007). "A Simple Panel Unit Root Test in the Presence of Crosssection Dependence". Journal of Applied Economics, 22(2), 265-312.

Pesaran, M. H., Ullah, A. ve Yamagata, T. (2008). “A Bias-Adjusted LM Test of Error Cross-Section Independence". Econometrics Journal 11, 105-127.

Pesaran, M. H. (2006). "Estimation and Inference in Large Heterogeneous Panels with A Multifactor Error Structure". Econometrica, 7484), 967-1012.

Pesaran, M. H. ve Yamagata, T. (2008). "Testing Slope Homogeneity in Large Panels". Journal of Econometrics 142, 50-93.

Rakhis, M. A. (2015). "Impact of Gender Inequality on Economic Growth in the Arab Region". Kuwait Program at Sciences Po. 
Eren, M. V. / Journal of Yasar University, 2020, 15/59, 598-614

Stevens, C. (2010). “Are Women the Key to Sustainable Development?". Sustainable Development Insights, Boston University, https://www.bu.edu/pardee/files /2010/04/UNsdkp003fsingle.pdf (04.02.2019).

Şimşek, M. (2010). “Türkiye'de Beşeri Kalkınma Bakımından Cinsiyet Eşitsizliği: Türkiye-Avrupa Birliği Karşılaştırması”. Uluslararası Sosyal Araştırmalar Dergisi, 3(13), 232-245.

Taş, H. Y. ve Bilen, M. (2014). “Avrupa Birliği Ve Türkiye'de Genç İşsizliği Sorunu Ve Çözüm Önerileri”. HAK-ISS Uluslararası Emek ve Toplum Dergisi, 3(3), 50-69.

Taş, H. Y., Küçükoğlu, M. ve Demirdöğmez, M. (2018). “Türkiye’de Genç İşsizliği Sorunu Ve Alternatif Çözüm Önerileri”. HAK-İŞ Uluslararası Emek ve Toplum Dergisi, 7(18), 279-294.

The World Bank. (2002). “Gender Equality \& Sustainable Development”. Gender and Development Group. Washington DC, http://siteresources.worldbank.org/INTGENDER /Resources/sustainable.pdf (04.02.2019).

Tunç, M. (2018). "Kalkınmada Kadın Ayrımcılığı ve Toplumsal Cinsiyet Eşitsizliğinin Rolü: Ülkelerarası Farklı Gelir Gruplarına Göre Yatay Kesit Analiz”. Sosyoekonomi, 26(38), 221-251.

Türkmen, Ü. A. (2016). "Kız Çocuklarının Geleneksel Anlayış İçindeki Rollerine İlişkin Tutumlarının Değişmesi”. (Ed. Rahman Çakır) Eğitim-Kadın ve Kalkınma, Ankara: Eğiten Kitap Yayıncılık, ss.211-217.

UNDP. (2019a). "5 Gender Equality", http://www.tr.undp.org/content/turkey/tr/home/sustainabledevelopment-goals/goal-5-gender-equality.html (06.02.2019).

UNDP. (2019b). "Human Development Report 2019", http://hdr.undp.org/sites/default/files/hdr2019.pdf (03.03.2020).

UNDP. Human Development Data (1990-2017). http://hdr.undp.org/en/data (22.10.2018).

Üner, S. (2008). “Toplumsal Cinsiyet Eşitliği. Kadına Yönelik Aile İçi Şiddetle Mücadele Projesi”, Kadının Statüsü Genel Müdürlüğü, Ankara.

Westerlund, J. (2008). "Panel Cointegration Tests of the Fisher Effect". Journal of Applied Economietrics, 23(2), 193-223.

World Bank (a). "Gender Statistics". https://databank.worldbank.org/data/source/gender-statistics (22.10.2018).

World Bank (b). "Population Estimates and Projections". https://databank.worldbank.org/source/population-estimates-and-projections (03.03.2020).

Yavuz, R. A. (2016). "Toplumsal Cinsiyet Eşitsizliği Ekseninde Kadın İstihdamı ve Ekonomik Şiddet”. Journal of Life Economics, 3(3), 77-100. 